\title{
The Top Level Design Analysis of Dual Class Equity System
}

\author{
Wang Bo Yu \\ Beijing Wuzi University, Beijing, China \\ wangboyu19936@163.com
}

\begin{abstract}
The development of multi-level ownership structure is a challenge and an opportunity for China's capital market. To research the dual class equity system in the angle of top-level design, we ought to make a change in giving the hightech, high hit, and blue chip companies the choice of ownership structure in order to adapt the fierce competition environment. The dual class equity system reform level include the strict standards, regulate the entry criteria; strict rules of information disclosure mechanism, guarantee transparency of information and fair environment; defining the subject of management, improve the protection of small investors interest mechanism. Through the overall planning and effective cohesion promote the perfection of the corporate governance structure of our country.
\end{abstract}

Keywords-ownership structure; dual class equity system; toplevel design

\section{INTRODUCTION}

With the rapid development of China capital market, the study of capital structure is not limited to a single system; Double ownership structure is gradually appeared on the extension of multi system of ownership structure and gradually gets into people's vision. The most important point that the dual ownership system from single ownership system is: dual ownership system with the shares of different rights, while the traditional ownership system is the same rights, specifically, the dual ownership system is the issuance of shares in the stock divided into A and B shares. A shares issued to specific groups of public common stock, mainly the public and institutional investors, the stock is only one vote or not vote; $\mathrm{B}$ is only in the internal management issue that generally not traded, but this vote per share has several times in the ordinary shares. The same rights is based on the perspective of equal shares, each share represents the same rights and obligations, attaches great importance to the protection of the interests of small shareholders is not damaged, maintain the stability of the capital market, The development of China's securities market is constantly changing and developing, Double equity system is the challenge and opportunity to the development of our securities market.

\section{THE THEORETICAL CONNOTATION AND PRACTICAL PROBLEMS OF DUAL SHAREHOLDING SYSTEM}

Foreign capital market has dual ownership system earlier, some of the world famous companies such as Google, Ford Motor Co, HP, Facebook, GM is used as a dual ownership system, the dual ownership system begin in the United States in 20s,which is produced in the family enterprises, with the development of the capital market, the family company expanding strong which need for external financing, But in order to maintain control of the family business, only a kind of property but no voting shares came into being. Now the development of listed companies with stock issuance, on the one hand, raise money for the company, on the other hand it has brought equity dilution, the more the number of shares issued, the more serious the equity dilution, which gradually lead to the original controlling shareholder lose control of the Company .

The dual ownership system produced in the family owned or controlled by a small number of people, the founder of these companies will control the decision-making power firmly in their own hands in order to maintain control of the company in the process of the company financing expanded, The study of DeAngelo (1985), Berrgstrom \& Rydqvist (1990) proved this point; while the implementation of the dual ownership system in listed companies will increase the agency cost, highly centralized decision-making is lack of efficiency, But Bohmer, Sangger \& Varshaney (1996) [1]believes that the shareholder returns and operating performance is better than the equity structure of the company. Wei Yongqiang (2012)[2] proved that little difference between the unitary companies in the scale, But the company performance and growth is better than single system Company, and the choice of double ownership structure is often composed of a variety of reasons. Liu Dao yuan (2012) [3] studied that the dual ownership structure can be introduced in our country from the point of view of the legislative value of the legislation, and made specific recommendations. Along with China's electricity supplier giants such as Baidu, Jingdong, Alibaba listing in the overseas, the domestic made a lot of research on the dual ownership system, Mayi(2014)[4] analyzed double ownership of Listed Companies in the U.S. state of the industry the likelihood that the higher the level of information industry for dual share more, the company law of our country the right to share the same principles to make the appropriate changes, the introduction of the system to maintain control of the company, but to draw its legal boundaries. Liu Lijuan (2015) [5]discussed the establishment of dual ownership system in China from the basic theory of the dual ownership system, Pan Liwen (2015)[6] studied dual ownership system research from the type settings of stock company. Liu Zongjin (2015) [7]analyzed the process of implementation of the dual equity Jingdong based on the Internet technology companies Jingdong, and analyzes the advantages and disadvantages of dual ownership, points out that perfecting the mechanism of 
legal protection of investors in China is the basis of the introduction of double equity system. As can be seen the domestic research on dual shareholding system initially concentrated in the system, and the research is mostly concentrated in the company law legislation in the perspective of Internet technology continues to flourish today, the reform of the stock right system should be developed to serve as the foundation of the capital market, the dual ownership system should not be complacent and introducing conditional based on the top-level design in Internet plus era, as the real legislative system, in order to meet the requirement of our listed companies on the stock system.

\section{ANALYSIS OF DUAL OWNERSHIP STRUCTURE OF LISTED COMPANIES IN CHINA}

\section{A. "Newcastle plan" of Baidu}

Baidu IPO launched the "Kraft plan" intended to prevent a hostile takeover, the stock is divided into class A shares and class B shares, the B shares have the right to vote 10 times in class A shares, shares held by the founder of B shares, so the founder at the general meeting of shareholders to vote will have absolute control right, specifically as long as the founder holds more than $11.3 \%$ of $\mathrm{B}$ shares will control the company Baidu, the two founders Robin $\mathrm{Li}$ and $\mathrm{Xu}$ Yong hold 34\% shares together, thus they control the company firmly.

\section{B. Partner system of Alibaba}

Alibaba launched the lake partner system at the beginning of the list, According to the partner system of Alibaba, the partner has a unique right to nominate the majority of directors of the board, but need go through the approval of shareholders. If the Alibaba partner was not nominated directors by shareholders, or for any reason left the board. The directors of Alibaba partners have the right to appoint another person to act as a temporary shareholder, until the next annual general meeting. Alibaba's partner system is a dual ownership structure, but the partner system make adaptive changes in order to listed in Hongkong, this system is not from the allocation of equity ratio to make strict requirements, which is to hold and founder of Alibaba shares had little direct contact, At this stage the Alibaba continues to have financing and expansion.

From the initial information provider, e-commerce platform to develop a large data cloud service platform Internet plus environment, financing scale expanding greatly diluted the proportion of shares held by the founder, but founder directly owns most of the right to nominate directors, and the founder can nominate their own directors, while retaining the right to nominate other shareholders to the board of directors. the board of this design will not change in the structure for a long time, although the founder of the team held a total of about $13 \%$ of the shares, but the business decision-making power to control the Alibaba, Partner system of Alibaba is separation of profit distribution right partner system and voting rights .

\section{Dual ownership structure of Jingdong}

Jingdong listed on NASDAQ in the United States in 2014, issued a Class A and class B stock, Liu Qiangdong the founder of Jingdong has the class $B$ shares of all the shares ,B shares can be converted into class A shares, class B shares have 20 times the class A shares super voting rights at the Jingdong IOP, Although the proportion of founder Liu Qiang East Equity accounted for only $20.66 \%$,however, it accounted for $83.7 \%$ of the vote, Liu Qiangdong, control of the Jingdong through the implement the dual ownership structure.

\section{Other company}

The company of technology innovation is developing rapidly under the background of the Internet plus, Ganyang (2015) analysis 91 listed companies in the NASDAQ, which adopts a multi ownership structure of the company a total of 15, more than 10 times the voting rights of 11 companies, including in software, services and retail industries. Most of these companies are Internet Co, Internet Co listed on the use of multiple ownership structure, not only meet the strong demand for financing during the start-up period, but also to maintain control of the company.

\section{EXAMINING THE DEVELOPMENT OF DUAL EQUITY SYSTEM FROM THE PERSPECTIVE OF TOP-LEVEL DESIGN}

The top-level design is using the method of system theory, from a global perspective on a problem from the end to the low-end in all aspects of the various elements of the overall planning, in order to focus on the effective resource improve the target. With the rapid development of Internet technology, more and more ecological Chinese in the high-tech listed companies seeking overseas listing, on the one hand, caused by the loss of high quality resources, on the other hand to the new problems of governance on the ownership structure of Listed Companies in the company law of our country, how to put forward a double equity system under the framework of the existing system? How to regulate the operation and practice of dual equity system? This is an urgent problem, in March 21, 2014, a surge of power under the conditions of the Securities Regulatory Commission published "preferred stock pilot management approach", the holders of preferred stock is superior to ordinary shareholders of profits and distribution of surplus property, but the company will participate in the rights policy management limited, a listed company may issue preference stocks, unlisted public company may issue preference shares of non-public, this is actively exploring multi-level equity structure. Dual ownership structure can not only maintain company's control of the founding team. But also can prevent malicious takeover effectively.

In conclusion, it is necessary to Chinese to accelerate the development of multi-level capital market, different enterprises have different demands on the dual ownership system in the process of development, the dual ownership system should also introduce. And take advantages of dual ownership system to improve equity structure. The establishment of dual level and multi-level equity system is based on a sound capital market, a good environment for supervision, and perfect information disclosure mechanism. Therefore, the development of double ownership structure should pay more attention to the top-level design, grasp the double ownership structure firmly, overall planning, reform is conducive to corporate governance environment for the development of double ownership system, 
supporting system research for double equity system strengths, the following aspects as the focus:

\section{A. Establish the strict standards of the dual equity system, standardize the entry criteria}

Establish the strict standards of the dual equity system, this requires our "company law" to promote the reform of the ownership structure actively, accelerate the pace of the pilot preference shares, according to the foreign advanced practice. We cannot completely open and not slow the pace. American introduction of dual shareholding system also experienced a discussion and controversy, a wave of mergers and acquisitions business in 1985, in the face of market environment changing and the need to enhance the competitiveness. With the change of market environment and enhance the competitiveness .New York stock exchange officially abandoned a right system in 1992. In the Internet environment, with the rapid development of enterprises, high-tech innovation, and these enterprises need a lot of financing but also have great requirements for the control of listed companies. Standards should be inclined to promote the development of small and medium-sized enterprises, to meet the kind of high tech, the needs of the company; also in different stages of development of listed companies with dual equity should have different standards.

\section{B. Strict information disclosure mechanism to ensure transparency of information}

Information asymmetry is a form of equity asymmetry. Reduce and eliminate information asymmetry is the effective measures to protect the interests of minority shareholders under the environment of market economy, It must implement the information disclosure mechanism strictly, especially for growth the expansion rate is higher, the blue chip listed companies, accurate and full disclosure of information enhance investor confidence and reduce the agency cost caused by information.

\section{Improve the mechanism of protecting the interests of small investors}

Management is a scarce resource. the market will be efficient only a clear management, rights and obligations are clearly defined.in the process of constructing the dual ownership in a strong binding force to maintain the decisionmaking power of managers, on the other hand to keep the unity of responsibility and interests in the right, the introduction of dual ownership system to improve the protection of the interests of the majority of investors mechanism as the premise, the development of China's securities market is not developed, Major shareholders damage the interests of the company. How to protect the interests of small investors is the core of dual ownership structure. Canada introduce double dovetail shares to increase maintenance of outside shareholders' rights; the United States securities group litigation system has become an effective means of small and medium shareholders to protect their rights and interests are not infringed, the number of times of different voting rights provisions into the company's qualification; according to the facts in our country. Based on the internal balance of corporate governance to ensure the use of human resource management and make corresponding restrictions, should be used as points of the reform of the company law comparison and reference.

\section{CONCLUSION}

Equity is a right or power, but also a resource. We take the same rights about the resource stocks. The initial allocation of rights, then the dual ownership structure can be regarded as the two allocation of equity. With the two allocation of equity, the economic value of equity, Social value is further stimulated and released, and the equity power is further developed, this is the logic of institutional change. The logic of institutional change of corporate law is from the bottom up, so the company law should be responsive. Domestic Internet giant companies because of the dual structure of the dual structure of the capital market to escape the domestic capital market, has a profound reflection of the market for dual equity structure of the system call.

The development of multi-level capital market to promote the overall development of global perspective, strict standards and continuous improvement of investors into the mechanism to protect the interests of investors is the key to the top-level design of double ownership system, internal control and stock control has been the core issue of corporate governance, system design of dual share appropriate to solve part of the equity control. Double equity introduced conditional can regulate the capital market and promote capital market development.

China has been allowed to issue preference shares, which in a way to break the Mandatory provisions of one share one right. As long as the use of dual equity structure is more likely to bring the benefits of agency costs, this system should be adopted; and the decisive factor in the size of the benefits and costs is the level of investor protection. In the case of investor protection, the negative effect of the dual ownership structure will be greatly inhibited, and its positive effect on the capital market will be brought into full play. Therefore, only by constantly improving the legal protection of investors in China's institutional construction, dual ownership structure is likely to develop in China's capital market, which has positive significance to promote the healthy development of China's capital market.

\section{REFERENCES}

[1] Boehmer , E., Sanger, G., Varshney, S., Levis, Mario, The Effect Consolidated on Performance: An of Dual-Class IPOs, Empirical Issues Raising Equity Capital, 1996, Control, Firm, in

[2] Wei Yongqiang. Dual ownership structure is a reasonable choice of the capital structure of the company [J]. Special Economic Zone, $2012,10: 115-117$.

[3] Liu Daoyuan. Efficiency and equity: the value choice of corporate law system design: a case study of Alibaba partner structure [J]. China business administration research, 2013, 12:35-38.

[4] Ma. In the process of dilution of equity, the control of the company is maintained: the legal approach and the boundary are the double ownership structure and Ma Yun's "Chinese partner system", [J]. 2014, 03:714-729.

[5] Liu Lijuan. Thinking about the establishment of dual shareholding system of Holdings Company [J]. 2015,02:48-49. 
[6] Pan Liwen. Dual equity issue: from the perspective of the types of shares of the company $[\mathrm{J}]$. Journal of Huazhong Normal University graduate students, 2015, 01:63-67.

[7] Liu Zongjin. Analysis of dual ownership structure of overseas listed companies of Internet technology: a case study of Jingdong [J]. 2015, 34:14-16.

[8] Gao Yang. Research on ownership structure of listed companies double [D]. Jilin University, 2015
[9] Li Haiying, Li Shuanghai, Bi Xiaofang. The dual ownership structure under the protection of the interests of small investors, China industrial economy, the case study of Facebook acquisition of WhatsApp [J]. 2017 (01): 1-19.

[10] HuPanpan. The dual ownership structure system and its legislative introduction [J]. Commercial Economic Research, 2016, (22): 116-117.

[11] Shang Peng. Interpretation of the institutional value of the dual ownership structure and the localization of [3]: A Study on the "partner system" of Alibaba group [J]. Hebei law, 2016, (05): 166-174. 